\title{
Diagnostics of CNC Machine Tools in Manufacturing Process with Laser Interferometer Technology
}

Jerzy Józwik ${ }^{1}$, Ivan Kuric², Milan Sága ${ }^{2}$, Paweł Lonkwic ${ }^{3}$,

${ }^{1}$ Mechanical Engineering Faculty, Lublin University of Technology, 36 Nadbystrzycka Street, 20-816 Lublin, Poland. Email: j.jozwik@pollub.pl

${ }^{2}$ Mechanical Engineering Faculty, University of Zilina, SK-010 01 Zilina, Slovak Republic. E-mail: ivan.kuric@ @stroj.utc.sk, milan.saga @ fstroj.utc.sk

${ }^{3}$ The Institute of Technical Sciences and Aviation, The State School of Higher Education, 54 Pocztowa Street, 22-100 Chełm, Poland. E-mail: pawel.lonkwic@lift.pl

The paper analyses the influence of the feed motion speed $v_{f}$ on the value of measured geometric errors of the fouraxis vertical machining centre CNC FV-580A with the FANUC 0IMB numerical control system. The tests were conducted with LSP 30 Compact laser interferometer (by Lasertex). Examples of modern, laser diagnostic systems of numerically controlled CNC machine tools were characterised in the article. Self-tracking laser interferometer LaserTRACER, diagnostic appliance LaserTRACER-MT, laser interferometer with XL80 with environmental parameters' measuring module XC80 and with heat sensors along with XR20-W calibrator were presented. Measurement results and their analysis were presented graphically in the form of diagrams and tables. The conclusion section comprises the discussion of the results, summary and deduction.

Keywords: manufacturing, CNC machine tools, diagnostics, diagnostic systems, laser interferometer

\section{References}

[1] BRYAN, J. B. (1982). A simple method for testing measuring machines and machine tools, Part 1. In: Precision Engineering, Vol. 4, 2, pp. 61. Publisher Elsevier.

[2] BRYAN, J.B. (1982). A simple method for testing measuring machines and machine tools. Part 2: In: Precision Engineering, Vol. 4, 3, pp. 125. Publisher Elsevier.

[3] CASTROA, H. F. F., BURDEKINB, M. (2006). Calibration system based on a laser interferometer for kinematic accuracy assessment on machine tools. In: Inter. Journal of Machine Tools \& Manufacture, 46(2006), pp. 89-97. Publisher Elsevier.

[4] DUGIN, A., POPOV, A. (2013). Increasing the accuracy of the effect of processing materials and cutting tool wear on the ploughing force values. In: Manufacturing Technology, Vol. 13, No. 2, pp. 169-173. ISSN 12132489

[5] CHEN, J.S., KOU, T.W., CHIOU, S.H. (1999). Geometric error calibration of -axis machines using an autoalignment laser interferometer. In: Journal of the International Societies for Precision Engineering and Nanotechnology, 23, pp. 243 - 252. Publisher Elsevier.

[6] HONCZARENKO, J. KWAŚNIEWICZ, J. (2008). Nowe systemy pomiarowe do sprawdzania dokładności obrabiarek CNC, Mechanik; 12: pp. 1012-1016. Publisher: Agenda Wydawnicza SIMP. Poland.

[7] IWASAWA, K., IWAMA, A., MITSUI, K. (2004). Development of a measuring method for several types of programmed tool paths for NC machine tools using a laser displacement interferometer and a rotary encoder, Precision Engineering, 28, 4: pp.399-408. Publisher Elsevier.

[8] JÓZWIK, J., KURIC, I., KRÁL, J. SR., KRÁL, J. JR., SPIŠÁK, E. (2012). Wybrane rozwiązania konstrukcyjne frezarek i centrów obróbczych sterowanych numerycznie. Postępy Nauki i Techniki, No. 13, Publisher: Oddział SIMP w Lublinie. Lublin. Poland. ISSN 2299-8624.

[9] KRYNKE, M., SELEJDAK, J., BORKOWSKI, S. (2012). Diagnosis and damage of bearings. In: Manufacturing Technology, Vol. 12, No. 13, pp.140-144. ISSN 1213-2489

[10] KURIC, I., DURICA, I., MADUDA, M. (2010). Accuracy monitoring and calibration of CNC machines. Scientific Bulletin, Serie C, Fascicle: Mechanics, Tribology, Machine Manufacturing Technology. Vol. XXIII, pp.113-118.

[11] LUKOVICS, P. (2013). Evaluation of vibration on technological devices. In: Manufacturing Technology, Vol. 13, No. 3, pp. 345-349. ISSN 1213-2489

[12] MAYER, K., PEXA, M., PAVLŮ , J. (2012). Impact of technical diagnostics interval on machinery maintenance. In: Manufacturing Technology, Vol. 12, No. 12, pp. 42-46. ISSN 1213-2489 
[13] MAJDA P. (2012). Relation between kinematic straightness errors and angular errors of machine tool. Advances in Manufacturing Science and Technology.Vol. 36, No. 1, pp. 47-53, Wrocław, Poland.

[14] MAJDA P. (2012). The influence of geometric errors compensation of a CNC machine tool on the accuracy of movement with circular interpolation. Advances in Manufacturing Science and Technology, Vol. 36, No. 2, pp. 59-67. Publisher Elsevier.

[15] NAKAZAWA, H., ITO, K. (1978). Measurement system of contouring accuracy on NC Machine Tools. Bull. Japan Soc. Prec. Eng.; 12, 4: 189. Publisher Elsevier.

[16] SCHWENKE, H., KNAPP, W., HAITJEMA, H., WECKENMANN, A., SCHMITTE, R., DELBRESSINE, F. (2008). Geometric error measurement and compensation of machines - An update. CIRP Annals - Manufacturing Technology, Vol. 57, 2: pp.660-675. Publisher Elsevier.

[17] http://etalon-ag.com/(z dn. 11/11/2013r.)

[18] http://www.renishaw.pl/pl/1030.aspx (z dn. 11/11/2013r.).

[19] http://www.lasertex.com.pl/ (z dn. 11/11/2013r.). 